Muhammad Yusuf Zaidan ${ }^{1}$; Moses Glorino Rumambo Pandin ${ }^{2}$

${ }^{1,2}$ Faculty of Humanities, Airlangga University, Surabaya

Jl. Dharmawangsa Dalam, Airlangga, Kampus B, Surabaya, East Java 60286

muhammad.yusuf.zaidan-2020@fib.unair.ac.id; moses.glorino@fib.unair.ac.id

\title{
BOOK REVIEW: \\ FILSAFAT DARI MASA KE MASA: MENGGALI KEBIJAKSANAAN PARA FILSUF \\ (PHILOSOPHY FROM TIME TO TIME: EXPLORING THE WISDOM OF THE PHILOSOPHERS)
}

Kurniawan; 146 pages; Prints to I 2020; Deepublish; 978-623-02-1783-8

"Filsafat Dari Masa Ke Masa: Menggali Kebijaksanaan Para Filsuf" of Philosophers is the work of Kurniawan as his belief in the responsibility of teaching philosophy that all audiences can understand with uncomplicated language but with a disingenuous discussion. Readers who are still laid to the world of philosophy will be invited by getting acquainted with the world of philosophy. It ranges from a basic understanding of philosophy, philosophy history, philosophy figures, and their thoughts, the purpose of studying philosophy, until introduction to the science of antiquity.

The author does discuss not only the basic knowledge of philosophy but also the history of the journey of philosophy to the present era, the thinking of significant figures that influence the development of philosophy (p.22-61), the benefits of studying philosophy and introducing to us and explanations of what is the science of Mantik (p.77), the history of science and its services (p.78-79).

Kurniawan will introduce us to the ins and outs of philosophy that managed to survive through some of the periods that have passed, coupled with the many philosophers' thoughts that are widely listed in this book, as well as the depiction of the author's view of how important it is to study philosophy in the future. Hence, it is unfortunate if not discussed further.

The book was written to explore the philosophical thinking of philosophers that developed over time. The concepts and contexts of philosophers' thinking flow follow the importance of clarifying a problem being answered constructively. Although the answers tend to be different, the spirit of unravelling them into us is just pieces of solutions stretched wide. Using the author's Mantic view leads us to the correct conclusion of the various explanations of philosophy in this book. This 5-part book is suitable for filling in questions to meet the needs of defectors who want to find out about etymology-terminology-history, philosophical figures, the development of philosophy, and the study of philosophy.

Kurniawan introduced us to the world of philosophy from the outside by explaining the basic concepts and objectives of the creation of philosophy. The new discussion is interesting when it begins to enter the eastern philosophical journey in chapter 2. The author invites us to dive into the world of Eastern Philosophy, which is the product of the intellectual thinking of Asian people, especially people located in China, Japan, India, and the East Asia region, which later called Islamic philosophy. In addition, chapter 3 is explained about the journey of philosophy in travelling through various periods since its birth in ancient Greece until the present era, which is packaged chronologically by the author. This chapter also introduces the science of Mantik and the author's explanation of the relationship between science, Technology \& Arts, Religion \&Amp; Culture, Civilization \& Destruction, Peace \& War, which is explained from a philosophical point of view. Interestingly the author also gives his perspective on Indonesia's independence which is still ironic to this day. Finally, in chapter 5, the author closes the discussion of this book by expressing his own opinion on the Vision and Mission of the study of philosophy.

There is a discussion that caught my attention in chapter 3 about the substance of the philosophical relationship between Colonialism \& the Domination of power. Kurniawan explained another meaning of colonialism. He wrote a sentence, "Colonization is not a matter of domination, but 
about domination that results in exploitation" (p. 98) which is the definition of colonization according to its actual reality.

This has to do with the discussion of what independence means. Independence in this book is defined as detached from the dominance and exploitation of the other party (p.98). The current state of Indonesia is independent of military colonization. But we are still in the grip of a foreign party wrapped in politics. The publication can see several revisions of the Law and new laws considered controversial for some audiences, such as the Minerva Bill that hints at all areas, including protected. Conservation may be exploration (1) that will threaten the sustainability of protected forests and conservation, and this policy is also considered to benefit only certain people.

On the other hand, the creation of the Copyright Work Law is also considered to facilitate the entry of foreign workers by changing and removing several rules related to the entry permits in Law No. 13 of 2003 on Employment (2). The adverse impact of this regulation is that the competition between Foreign workers and local workers is becoming more widespread, which can be seen in various lives in various regions. Foreign workers who come to Indonesia work in multiple fields, both in education, construction, manager, and labour. Foreign workers have visited almost a considerable area of work today. The arrival of foreign workers in Indonesia does not bring problems to the Indonesian workforce. This can be seen from the high unemployment rate in Indonesia that can lead to social conflict between Indonesian workers and foreign workers (3). Both examples prove there is still the influence of exploitation and dominance from outside and inside Indonesia.

In this book, the author also describes his view on the irony of Indonesian independence on page 103, which will preview attach the author's opinion in the discussion of the book highlights.

While reading this book, I became aware that philosophy had a long journey to stay afloat in every period that had gone on since its birth. His journey was accompanied by the thoughts of new philosophers who often introduced a new concept as science developed. Philosophy is also not just an abstract science that we can not apply in life. With philosophy, we can hone our reasoning skills, build a foundation of thinking, and help us always to

reason.

The book is divided into five sections that are interrelated with each other. Sections 1 and 3 give us an idea of what philosophy is, which is summarized in such a way as to be easily understood and accompanied by the opinions of some experts, further explaining how the history of philosophy born and developed through several essential periods. Part 2 Introduces us to important philosophical figures from the ancient Greek era to the present age. Explanations per character are summarized interestingly with a brief biography and philosophical thoughts of each figure. Sections 4 and 5 of the authors explain how important it is to study philosophy, which dukes put forward in some critical points because philosophy has various benefits when we look at it diligently. Finally, the discussion is closed by section 5, which contains the author's view of the Vision and Mission of philosophy learning. Below are my recaps and highlights of each chapter in the book:

Part 1 begins by discussing the understanding of philosophy and the brief history of the emergence of philosophy. Semantic: the word philosophy' comes from the Arabic 'philosophy', which comes from the Greek, 'philosophia', which means philos-love, and 'sophia' knowledge, wisdom. So philosophia' has a meaning that means love. People who love knowledge are called 'philosophers', in Arabic failasuf". People who devote themselves to learning and make ability the basis of life is referred to as lovers of expertise (4). Plato (423-347 BC) had his explanation for philosophy. He said philosophy was the source of all knowledge. According to al-Farabi, philosophy is a science that investigates the nature of significant and its wildlife. From some of the above understandings can be concluded that Philosophy is a science that has a particular uniqueness in answering questions that can not be answered by ordinary science because it is beyond the reach of the usual mindset of knowledge (p.2).

Thales was the first philosopher to make a study of the early nature of ancient Greece. He said water is the most essential element for living things because water can turn itself into steam, ice, and gas. In addition to thales ancient Greek period also had several other philosophers such as Plato and Parmenides. Ancient Greece reached its golden age during the time of Aristoteles and Socrates. 
He entered a period of darkness that began from the 12th to 13 th centuries AD. At this time, philosophy tends to suffer setbacks. The king limited freedom of thought which made philosophical thinking suspended. The church only owns the truth, and science seems to freeze. In modern times philosophy began to develop, marked by the emergence of new traditions such as Rationalism presented by Rene Descartes, Empirism gave by David Hume, and Kritisme presented by Immanuel Kant. The development of this philosophy continued into the post-modernism period that began around the 18th to 19th centuries AD - characterized by the emergence of new traditions such as Marxism, existentialism, pragmatism, Neo-Kantianism, phenomenological neo-Tomism, capitalism, and Positivism.

Part 2 is included in the introduction of philosophical figures from representatives of Western formations, Islam, Christianity, Atheists. Beginning with Plato, Immanuel Kant, Karl Max, Rene Descartes as representatives of western philosophical figures with their famous thoughts and works such as Discours de la Methode, Meditationes de prima Philosophia, Republika, etc. From Islamic philosophy, there are Al Farabi, Al Razi, Ibn Rusyd, and Ibn Sina. With their famous thoughts such as Sufism, Prophethood, etc. In Christian philosophy, there are Thomas Aquinas figures whose theological writings, especially summa theologia, are perhaps the most powerful statement in Catholic theological doctrine ever. It is not wrong to say that no one has ever worked on a philosophical system as complete, detailed, and as thought-good as Thomas Aquinas. Finally, for the author's Atheist philosophers to get to know Ludwig Andreas Feuerbach more deeply with his view that God is a projection of man, Feuerbach, opposes Hegel's saying that God is not real and created from human wishful thinking.

The author invites us to dive into the world of Eastern Philosophy, which is the product of philosophical thinking of Asian people, especially people located in China, Japan, India, and East Asia, which will be called Islamic philosophy and some other Asian regions. This philosophical thinking is very plural and looks at the social and cultural conditions that exist. This Eastern philosophy has a fundamental difference from Western philosophy related to religion.

Part 3 focuses on the period of intellectual development divided into eight periods, namely the Greek period as the first period of intellectual development, the Period of Hellenity and Rome, the Patriarchal period, the Islamic period, the Scholastic period, the Middle Ages period, the Modern period, and the New Era.

The Greek period had three early periods called the development period covering the early period, the period of the sophists, and the heyday. This period of philosophy only examines the nature and scientific events of the changes that occurred at this time. The Helenitas and Roman periods alone could not be separated from the role of a Great Alexander. Nevertheless, he succeeded in transforming Greek culture into a new culture called Helenitas. At this time, he opened a new school and managed to defeat the existence of Akademia Plato. This led to the emergence of new philosophical thinking such as Skepticism, Epicurism, and Neoplatonism.

In the Patristic period, Christian theology came in as part of philosophy, and there was a conflict among Christian religious leaders in understanding philosophical thinking. Because it is considered to lock the human mindset in philosophy if the thought is contrary, then immediately punished. This made secularism appear to separate religion and philosophy.

Furthermore, it entered the period of Islamic philosophy that arose due to a massive translation of the book of Greek civilization and others during the Abbasid period. Therefore, Islamic philosophy itself has its character compared to Greek philosophy that is in Islam is a rational religion that wraps its philosophical thinking in the curtain of religion. Therefore, philosophy has its limits to enter into this philosophical thought and is forbidden to undermine the religion of Islam itself.

After the Islamic period of scholastic period, philosophy has the characteristics of serving theology by synthesising reason and belief. This period has a fundamental difference with patristics in discussing theological studies, namely using philosophy as a means of proof. It came in the medieval period when most people began to be saturated with the authoritarian attitudes of the church in limiting their thinking of something. Because at that time, the thought that is considered incompatible with the 
idea of the church will get the stigma of "infidels" and get severe punishment. Therefore, there was an attempt to separate science and religion to get a bright spot in freedom of thought.

The Modern Period emerged as Enlightenment to theological understanding that turned off thought in Europe for ten centuries by bringing a movement aimed at circulating the church, which in its course always limited the human mindset. This movement was named "renaissance," which means rebirth. The spirit of this movement gave rise to the belief in the right of human autonomy in seeking truth. Science developed rapidly due to this movement, and truth no longer sourced from the Bible but instead on empirical thinking and the formulation of a rational hypothesis. From this comes a new thought called Rationalism and Empirism as the fruit of the source of knowledge that man, namely reason and experience, can use.

A new era began with the emergence of a new understanding called Positivism introduced by Auguste Comte (1798-1857). This school is considered the highest flow in human life because a fact is available without finding the cause man only needs to create a relationship or relationship of similarities and sequences between the points. Then also came a new tradition called Phenomenology, popularized by Edmund Husserl (1859-1938), where this philosophical thought has the essence that to find a correct thought, one must return to the nature of the object itself. The next emerging new tradition was Existentialism, popularized by Friedrich Wilhelm Nietzsche (1844-1900) with the core thought that "existence precedes essence", which means man must find himself because a human being without existence is nothing. In this chapter also, the author introduces to the reader The Science of Mantik. This science is considered the father of all sciences because it becomes our tool leading to the correct conclusion.

The author also gave evidence of the Irony of Indonesian Independence. He said that the celebration of Indonesia's independence is pseudo. Because basically, the dominance of other nations against Indonesia is still happening, but in other ways, such as the interpretation of the ideology of Capitalism-Secular on behalf of diplomatic relations in terms of exploitation, natural resources, and human resources of this country has been deprived by foreigners. Indonesia's natural wealth flows more abroad than it lives its own people in the country. Examples are the Foreign Investment Law, Minerva Law, Oil and Gas Law, SJSN and BPJS Law, KDRT Law, etc. This does not include other regulations such as Presidential Decrees, Ministerial Regulations, and others that also strengthen various rules that are exploitative. This is the form of exploitation of other nations against the People of Indonesia. Domination and exploitation, not in militaristic form, but more political. (p.103). The author regrets that the country is only independent of the outside but still in the grip of foreigners.

Part 4 is explained about The Study of Philosophy. This chapter reveals how important the study of philosophy outlined that studying philosophy has main objectives: instilling curiosity, forming mental attitudes and disciplines, training in problems, reading problems wisely, and wanting glory. Furthermore, philosophy is helpful for seeing issues from all points of view and pioneering us in creating a critical, independent and adaptable mindset in a life cycle that often changes.

Part 5 closes with the author's new view by creating a Mission and Vision of the study of philosophy itself. The vision presented by the author in part 5 is Enlightenment (meaning to give a view to the science of philosophy itself); Honing (Helping us to hone our inner abilities to do positive activities); Mobilizer (Moving ourselves to do things that are of positive value and benefit to others). While the mission of philosophy learning is summarized into 4 points, namely developing knowledge, bringing glory, developing thinking, and engaging in life.

This book is highly recommended for beginners who want to know more closely about philosophy. It has its advantages by introducing Mantik Science as one of the critical discussions in this book. Mantik science itself is a science used to overcome mistakes in thinking. With the use of the science of Mantik, the writing of this book will be directed by the author at the correct conclusion. The author summarizes philosophy in a language that is easy to understand by using effective and incomprehensible sentences. Explanations of history are also applied chronologically and accurately. Plus, the evidence of philosophical correlation with the world's problems today adds to the appeal of this book by Kurniawan. 
However, the book still has some shortcomings that are explanations that tend to jump around to not correspond to the substance spoken of. This can be seen in chapter 4, which focuses on introducing philosophical figures (p.76). Suddenly, a new explanation of The Science of Mantik is irrelevant to the main discussion in the chapter. This confuses the reader because one topic and another tend not to have a related relationship. In addition, there are some writing errors, such as chapter 3 (p.63), which writes the development of philosophy consisting of 5 periods. Whereas in the written explanation with jellies, that philosophy developed in 8 periods.

Wholly, the book is highly recommended for novice readers, especially students who want to study philosophy, because this book is present to fill the discussion room about etymologyterminology-history, philosophical figures, the development of philosophy, as well as the study of philosophy. The author organizes this book by bringing us to an easy-to-understand basic explanation of the substance to be discussed, only to enter into the core of the discussion. Readers do not even have to ask what they know because the answers are already available in this book.

For book author, it would be nice to break down part of the book even more. To make it easier for the reader to understand the discussion referred to in one section is called. Because when forced, the debate becomes ambiguous and does not correlate between sati with each other (see in the book shortage). It would be nice if the author uses more references from journals and books that are more recent and accurate, especially in giving an opinion on a problem. In addition, I advise writers to have a personal medium as a tool to explain more deeply about philosophy through perfecting the work that has been published and as a source of information for the reader.

For readers, the whole book is not too difficult to understand. However, in some sections, there are still discussions that do not correlate with each other, making the reader confused about the previous meeting. After reading this book, I recommend you add to your reading, especially the book about Mantik, because this book manages to bring you to the outer skin of the discussion about the science of Mantik, and it does not hurt if you deepen it again. This book also gives you new knowledge outside of philosophy, such as historical and religious knowledge. So, it doesn't hurt to read the book right away.

Muhammad Yusuf Zaidan \& Moses Glorino Rumambo Pandin Airlangga University

\section{REFERENCES}

1. Abduh R. Dampak Sosial Tenaga kerja Asing ( TKA ) Di Indonesia. Sosek:Jurnal Sososial dan Ekonomi. 2020;1:26-7.

2. Muhammad Idris. UU Cipta Kerja Disahkan, Tenaga Kerja Asing Makin Mudah Masuk RI [Internet]. Kompas.com. 2020 [cited 2021 May 24]. Available from: https://money.kompas.com/read/2020/10/06/143238626/uu-cipta-kerja-disahkan-tenaga-kerja-asingmakin-mudah-masuk-ri?page $=$ al

3. Rahayu W. Filsafat, Etika Dan Ilmu: Upaya Memahami Hakikat Ilmu Dalam Konteks Keindonesiaan. AnNuha. 2019;17(1):80.

4. Richaldo Hariandja dan Della Syahni. UU Minerba Baru Makin Ancam Hutan Lindung dan Konservasi [Internet]. https://www.mongabay.co.id/. 2020 [cited 2021 May 24]. Available from: https://www.mongabay.co.id/2020/06/04/uu-minerba-baru-makin-ancam-hutan-lindung-dan-konservasi

AUTHOR: Kurniawan bin Muhammad Nuh bin H. Nga Ilyass bin As Somad was born in Meranjat, Palembang on December 7, 1972 to a couple (Alm.) Muhammad Noah and Jazilah. He has a wife named Rowyah Elva N.A. and three children, Irfan Qowwiyul "Aziz Al-Hajj, Ahmad Rofiq Al Faruq, and Muhammad Arief Kurniawan. It is located at Jalan Cokroaminoto No. 13 Talang Rimbo Baru Village, Curup, Rejang Lebong. Primary school education in Meranjat, junior high school in Meranjat, high school in Lubuk Linggau, S-1 at IAIN Raden Fatah Palembang, S-2 and S-3 at Padang State University. He currently serves at STAIN Curup as a lecturer in the tarbiyah department, Islamic Religious Education Program, and Tadris English. The courses are General Philosophy, Philosophy of 
Science, Islamic Philosophy, Philosophy of Islamic Education, Educational Thought, Educational Sciences, Management of Islamic Education, Class Action Research, Educational Research Methods, Civic Education, and Mantiq sciences. 